\title{
STAVOVI STUDENATA PEDAGOGIJE PREMA RAZVOJU PEDAGOŠKOG I ŠKOLSKOG PLURALIZMA*
}

U tekstu se polazi od stanovišta da obrazovanje u pluralnom društvu zahteva prilagođavanje školskog sistema uslovima novog vremena, što u našoj obrazovnoj realnosti aktualizuje pitanje pedagoškog i školskog pluralizma. Polazeći od stava da relativno nova situacija u našoj zemlji pretpostavlja aktivne, autonomne i odgovorne pedagoge osposobljene da odgovore na potrebe pojedinca i društva u kontekstu demokratskih procesa, cilj istraživanja odnosi se na sagledavanje stavova studenata pedagogije prema privatnim i alternativnim školama. Primenjeni instrument kreiran je za potrebe ovog istraživanja, a uzorkom je obuhvaćeno 99 studenata pedagogije. Dobijeni rezultati pokazuju da većina ispitanih studenata pedagogije Filozofskog fakulteta Univerziteta u Novom Sadu ima relativno pozitivan stav prema privatnim i alternativnim školama, pri čemu odgovori studenata uglavnom naginju ka isticanju prednosti privatnih u odnosu na državne škole. Rezultati takođe pokazuju da ispitanici, generalno posmatrano, procenjuju da su malo informisani o alternativnim pedagoškim koncepcijama. Međutim, utvrđeno je da su studenti IV godine informisaniji o alternativnim pedagogijama u odnosu na studente II godine. Zaključuje se da je u cilju unapređivanja kvaliteta obrazovanja veoma važno raditi na informisanju svih aktera vaspitno-obrazovnog procesa o delovanju alternativnih i privatnih škola, kao i na uvođenju sadržaja iz područja pedagoškog i školskog pluralizma u programe nastavničkih fakulteta.

Ključne reči: alternativne škole, demokratizacija društva, pedagoški i školski pluralizam, privatne škole, studenti pedagogije.

\section{UVOD}

Promenjene okolnosti savremenog sveta obrazovanju daju ključnu ulogu u pružanju odgovora na izazove koje donose globalne razvojne promene. Od sedamdesetih godina 20. veka pa do danas problemi škole i obrazovanja gotovo u svakoj zemlji tretiraju se kao socijalna pitanja od prvorazrednog značaja. Ipak, opšte nezadovoljstvo školom razlog su njene kontinuirane kritike i pokušaja unapređenja kvaliteta obrazovanja. Reč je o tome da je tradicionalni sistem školstva, nje-

\footnotetext{
dr Jovana Milutinović, e-mail: arcus@neobee.net

Rad je nastao u okviru projekata „Kvalitet obrazovnog sistema Srbije u evropskoj perspektivi“ (179010) i „Pedagoški pluralizam kao osnova strategije obrazovanja“ (179036) koje u periodu od 2011. do 2014. godine finansira Ministarstvo prosvete, nauke i tehnološkog razvoja Republike Srbije.
} 
gova organizacija i unutrašnje uređenje, prestao da bude funkcionalan i efikasan, jer ne stiže i po svojoj suštini ne može da stigne da reaguje na potrebe i zahteve novog društva. Javlja se, dakle, potreba za reformama i promenama, koje u raznim delovima sveta prodiru sa različitim intenzitetom i sa različitim uspehom (Ridl, 2003). Ovi reformski zahtevi, pretežno fokusirani na utemeljenje nastave orijentisane ka učeniku, na obrazovanje koje će biti bliže prirodi i potrebama deteta, na promovisanje pedagogije aktivnog učenja i sticanja upotrebljivih znanja i veština, na razvoj demokratije u društvu i slično, nisu novi.

Naime, u prvoj polovini 20. veka u Evropi i Sjedinjenim Američkim Državama javljaju se pokreti reformske pedagogije, novog ili progresivnog obrazovanja, a mnogi pravci i modeli nastojali su da prevaziđu slabosti i nedostatke škole, nastave i obrazovanja. Proces kritičkog preispitivanja konvencionalnog školovanja nastavljen je i u narednom periodu, što je rezultiralo, između ostalog, osnivanjem privatnih i alternativnih škola tamo gde je to demokratsko društveno uređenje dozvoljavalo. Tako se uz politički pluralizam u društvima sa razvijenom demokratijom razvija i pedagoški i školski pluralizam. Dok se pod pedagoškim pluralizmom podrazumevaju aktivnosti vezane za organizaciju nastavnog procesa $u$ školama, odnosno primenu raznovrsnih teorijskih orijentacija i koncepcija reformske pedagogije, pojmom pluralizam školstva obuhvata se celina političkih i organizacionih rešenja u sistemu obrazovanja koja treba da efikasno doprinesu promenama u demokratskom društvu (Krbec, 1999, 269). Iako je školski pluralizam povezan sa delovanjem privatnih i alternativnih škola, značajno je napomenuti da ova dva koncepta nisu sinonimi, te da nije ispravno izjednačavati pojmove privatno i alternativno obrazovanje (Milutinović \& Zuković, 2013).

Pojam privatno obrazovanje često se upotrebljava kako bi se označilo ono obrazovanje koje ne pripada kategoriji javnog obrazovanja. Ipak, privatno obrazovanje predstavlja koncept kojim se obuhvata raspon veoma različitih situacija. Prema najčešćim tumačenjima pojam privatno obrazovanje obeležava onaj oblik obrazovanja koji osniva i finansira pojedinac, nevladino telo ili asocijacija koja podleže odgovarajućim zakonima (Eurydice European Unit, 2000, 10). Unutar ovog sektora, međutim, postoji razlika između privatnog obrazovanja u njegovom striktnom značenju i budžetski potpomognutog privatnog obrazovanja. Dok privatne obrazovne institucije u striktnom značenju u celini finansira pojedinac ili nevladino telo, budžetski potpomognute privatne obrazovne institucije primaju određenu finansijsku pomoć od državnih vlasti koja može, ali i ne mora da bude značajna.

Kada je reč o alternativnim školama, treba napomenuti da su one postale posebno aktuelne nakon kritike državne škole za koju je zajednička (kritička) ocena da ne zadovoljava ni potrebe društva, a ni potrebe pojedinca (Vrcelj, 2000, 34). Ovde se otvara pitanje tumačenja samog pojma alternativna škola koji se u literaturi definiše na različite načine (Milutinović, 2011; Nagata, 2006; Raywid, 1999; Sliwka, 2008; Spevak, 2001). Neki autori (Ridl, 2003) ističu da alternativna može biti bilo kakva škola ili pokret u odnosu na drugi pokret ili školu, zavisno od as- 
pekta, pristupa ili kriterijuma koji se odabere kao određujući. Ovde se radi o korišćenju pojma alternativna škola sa šireg gledišta. Uže posmatrano, uvek su u pitanju samo škole koje su bile obeležavane pojmom alternativne od sedamdesetih godina 20. veka, u vreme nezadovoljstva javnosti sadržajem i organizacijom javnog školstva i osnivanja škola na osnovu predstava nekih društvenih grupa. Sa tog gledišta prioritetni kriterijum određenja pojma alternativna škola predstavlja sama pedagoška specifičnost određene obrazovne institucije. Posmatrano u ovom kontekstu alternativne su one škole koje karakteriše obrazovanje usmereno na dete i njegovu individualnost, inovativan i fleksibilan kurikulum u kojem se polazi od učeničkih potreba i interesovanja, partnerski odnos u nastavi, aktivno učešće učenika, roditelja i interesnih grupa u školskom životu i razvoju škole i tako dalje. U tom okviru alternativno obrazovanje podrazumeva ono obrazovanje koje se razlikuje od dominantnih obrazovnih tokova koje reprezentuje država, a može se realizovati i u javnim i u privatnim školama.

\section{PEDAGOŠKI PLURALIZAM I POLITIKA ŠKOLSKOG IZBORA}

U većini zemalja Evropske unije danas postoji veoma širok spektar prakse u pristupima slobodi školskog izbora, a prilike za izbor između različitih škola, kako unutar državnog sistema, tako i između državne i privatne ponude danas su pre pravilo nego izuzetak. I one zemlje gde je obrazovanje označeno kao javno dobro uz snažnu veru u jednakost (na primer, nordijske zemlje) podstiču pluralizam obrazovnih sistema (Milutinović, 2011). Ovde se otvara pitanje spornih argumenata na relaciji kvalitet i jednakost, pri čemu su stanovišta u pogledu oslanjanja na mehanizme slobodnog tržišta u obrazovanju polarizovana i nesumnjivo veoma subjektivna.

Protivnici privatnih škola i privatnog obrazovanja tvrde da prihvatanje politike školskog izbora dozvoljava mogućnost da će neki učenici primiti bolje obrazovanje od drugih, da se tržišni pristup neprikladno primenjuje u području obrazovanja, te da se njegovim uvođenjem napušta najvažnija funkcija javnog obrazovanja koja se ogleda u prenošenju zajedničkih kulturnih vrednosti od nacionalnog interesa (Sliwka \& Istance, 2006, 45). Kritičari školskog izbora smatraju da obrazovanje nije ,potrošna roba”, već javno dobro pomoću kojeg društvo ostvaruje svoje ciljeve (Savićević, 2000, 189). Stavovi suprotni neometanom roditeljskom izboru, a u vezi sa poboljšanjem kvaliteta obrazovanja, zasnivaju se na ubeđenju da uvođenje principa slobodnog tržišta na polje obrazovanja produbljuje postojeće klasne i socijalne nejednakosti (Boyd, 2005). Veruje se da postojeći ekonomski i obrazovni dispariteti kreiraju uslove koji u praksi ishode umnožavanjem prilika i pogodnosti za one koji su već privilegovani i ograničavanjem prilika za one kojima su mogućnosti za napredovanje najpotrebnije.

Sa druge strane, rasprostranjeno je uverenje prema kojem mogućnost izbora škole predstavlja značajno sredstvo poboljšanja kvaliteta obrazovanja (Milutinović, 2011). Pristup da se škole dovedu u situaciju da se izbore za učenike na principima 
koji vladaju u tržišnoj ekonomiji, prema pristalicama školskog izbora, uvodi raznolikost u uniforman obrazovni sistem, te rešava problem osrednjosti javnog obrazovanja koji nastaje usled državnog monopola. Zastupnici privatnih škola i privatnog obrazovanja računaju na mnoge prednosti koje proizilaze iz primene politike školskog izbora. Oni tvrde da implementacija politike školskog izbora respektuje individualne talente, uzimajući u obzir ogromne razlike u sposobnostima, potrebama i ciljevima učenika. Pristalice privatnih škola tvrde da mogućnost izbora škole podržava pravo etničkih i kulturnih grupa i njihov identitet. Grupisanje u školama omogućava multietničkim zajednicama da sačuvaju i neguju svoju kulturu i tradiciju (Boyd, 2005). Takođe, tvrdi se i da izbor škole podstiče angažovanje roditelja u obrazovanju vlastite dece i povećava obrazovne mogućnosti za neke siromašne, pa samim tim i oštećene učenike (OECD, 1998, 165). Veruje se da sprovođenje politike školskog izbora osigurava dostupnost širem rasponu izbora školovanja, oslobađa neprivilegovane od birokratije javnih škola, te ih osnažuje po pitanju odabira kvalitetne škole. Pri tome, većina argumenata u pogledu odbrane školskog izbora zasniva se na stavu da mogućnost izbora predstavlja temeljni princip pluralnog demokratskog društva.

U Izveštaju stručnjaka OECD-a (Hirsch, 2002) se ukazuje da školski izbor ima raznovrstan uticaj na obrazovne sisteme; on se povezuje sa kontinuiranom debatom i reformom na sistemskom nivou koja u nekim slučajevima ishodi velikim aspiracijama i očekivanjima, a u drugim razočarenjima na individualnom nivou. Određene okolnosti u kojima se odvija školski izbor mogu imati, kako pozitivne, tako i negativne uticaje na kvalitet obrazovanja. Radi se o tome da efekti školskog izbora zavise od modaliteta, uslova i socio-kulturnog konteksta u kojem se taj izbor realizuje. Otuda je od ključnog značaja kreiranje i podržavanje politike obrazovanja koja uređuje i reguliše školski izbor na pravedan i socijalno prihvatljiv način.

Pored činjenice je da većina zemalja Evropske unije ima višedecenijsko iskustvo u funkcionisanju privatnih i alternativnih škola, značajno je naglasiti da su se na samom kraju 20. veka za ove škole zainteresovale i one zemlje gde je pedagoški i školski pluralizam bio onemogućavan (Milutinović \& Zuković, 2013). U tom smislu su u mnogim zemljama centralne i istočne Evrope (Mađarska, Poljska, Češka Republika, Slovačka Republika, Republika Hrvatska ...), obrazovne reforme pokrenute procesima tranzicije, političke demokratizacije i pluralizacije društva uključivale i ponovo uspostavljanje sektora privatnog obrazovanja i osnivanje alternativnih škola. U ovim zemljama privatno i alternativno obrazovanje se vezuje sa pravom građana na izbor obrazovanja (Sliwka \& Istance, 2006), i posmatra kao doprinos pluralizaciji društva u postsovjetskoj eri. U našoj zemlji, međutim, slični uslovi stvorili su se sa značajnim zakašnjenjem, to jest praktično na samom početku 21. veka. Zakonom o osnovnom obrazovanju i vaspitanju iz 2013. godine (Zakon o osnovnom obrazovanju i vaspitanju, 2013) uveden je termin škola posebne pedagoške orijentacije, te je omogućeno osnivanja privatne škole kao škole posebne pedagoške orijentacije (Montesori, Dekroli, Stajner i slični programi), kada Ministarstvo utvrdi da realizacija njihovog programa obezbeđuje 
ostvarivanje standarda za završetak osnovnog obrazovanja. Pri tome, Zakonom je određeno da privatna škola kao škola posebne pedagoške orijentacije mora da poseduje sertifikat međunarodno priznatog udruženja škola iste pedagoške orijentacije.

U celini posmatrano, opšta tendencija koja je naročito uticala na oblik školstva u 20. veku je stalno širenje demokratizacije obrazovanja u smislu povećanja raznovrsnosti ponuda obrazovnih sadržaja, metoda i oblika rada, kao i organizacije mogućnosti izbora najrazličitijih puteva koji vode osvajanju traženog obrazovanja (Ridl, 2003, 343). Ovakva tendencija predstavlja imperativ i za proces reforme obrazovanja u Republici Srbiji, što svakako nameće potrebu prilagođavanja aktuelnog školskog sistema uslovima novog vremena, ali i potrebu osluškivanja stavova različitih interesnih grupa prema razvoju pedagoškog i školskog pluralizma, a posebno budućih pedagoga koji će biti pozvani i u poziciji da inovativno i kreativno upravljaju promenama u oblasti obrazovanja. Polazeći od stava da relativno nova situacija u našoj zemlji pretpostavlja aktivne, autonomne i odgovorne pedagoge osposobljene da odgovore na potrebe pojedinca i društva u kontekstu demokratskih procesa, u daljem tekstu će biti sagledani stavovi studenata pedagogije prema značaju delovanja pedagoškog i školskog pluralizma, kao i njihova procena vlastitog nivoa informisanosti o različitim alternativnim pedagoškim koncepcijama.

\section{METODOLOŠKI OKVIR ISTRAŽIVANJA}

Cilj i zadaci istraživanja. Cilj istraživanja odnosi se na sagledavanje stavova studenata pedagogije prema privatnim i alternativnim školama. Ovako postavljen cilj istraživanja operacionalizovan je kroz sledeće istraživačke zadatke:

1. Ispitati kakvo je mišljenje studenata pedagogije o značaju delovanja privatnih i alternativnih škola.

2. Ispitati kakvo je mišljenje studenata pedagogije o distinktivnim obeležjima privatnih škola u odnosu na državne škole.

3. Ispitati kako studenati pedagogije procenjuju svoj nivo informisanosti o različitim alternativnim pedagoškim koncepcijama.

4. Ispitati kakvo je mišljenje studenata pedagogije o potrebi povećanja broja alternativnih škola u Srbiji.

5. Ispitati da li postoje statistički značajne razlike u odgovorima studenata pedagogije zavisno od godine studija.

Instrument istraživanja. U cilju realizacije postavljenih istraživačkih zadataka primenjen je instrument koji je konstruisan za potrebe ovog istraživanja ${ }^{1} \mathrm{i}$ koga čine dva dela.

Instrument je konstruisan prema modelu sličnog instrumenta koji je primenjen na teritoriji Republike Hrvatske (Rajić, 2008), s tim što su određena pitanja modifikovana i prilagođena u skladu sa specifičnostima aktuelnog obrazovnog konteksta Republike Srbije. 
Prvi deo instrumenta sastoji se iz dve skale. Prva skala sadrži 10 ajtema koje se odnose na značaj delovanja privatnih i alternativnih škola. Ispitanicima je pružena mogućnost da na petostepenoj skali Likertovog tipa (1 - uopšte se ne slažem; 2 delimično se ne slažem; 3 - neodlučan/na sam; 4 -delimično se slažem; 5 -u potpunosti se slažem) izaberu jedan od ponuđenih odgovora. Rezultati faktorske analize pokazuju da je reč o jednodimenzionalnoj skali (procenat objašnjene varijanse prve izolovane komponente iznosi 41,27, a druge upadljivo niže - 12,82), a u prilog tome govore i korelacije ajtema s prvom glavnom komponentom koje su sve više ili visoke, i preko ,44 (Tabela br. 1). Takođe, rezultati faktorske analize ukazuju na visok nivo unutrašnje konzistentnosti ajtema (Alpha koeficijent isnosi 0,83).

Tabela 1. Faktorska analiza skale o značaju delovanja privatnih i alternativnih škola

\begin{tabular}{|c|l|c|}
\hline \multicolumn{2}{|c|}{ Ajtemi } & Komponenta \\
\hline 7. & $\begin{array}{l}\text { U alternativnim školama više se vodi računa o potrebama i } \\
\text { interesovanjima svakog deteta. }\end{array}$ &, 768 \\
\hline 10. & $\begin{array}{l}\text { Država treba da finansijski potpomaže otvaranje i delovanje } \\
\text { privatnih i alternativnih škola kako bi one bile jednako dostupne } \\
\text { svoj deci. }\end{array}$ &, 757 \\
\hline 8. & $\begin{array}{l}\text { U alternativnim školama odvija se kvalitetnija komunikacija } \\
\text { između nastavnika i roditelja. }\end{array}$ &, 738 \\
\hline 9. & U privatnim školama obezbeđuje se viši nivo bezbednosti učenika. &, 657 \\
\hline 5. & $\begin{array}{l}\text { U privatnim školama učenici se bolje pripremaju za nastavak } \\
\text { obrazovanja na višim nivoima. }\end{array}$ &, 651 \\
\hline 4. & $\begin{array}{l}\text { U privatnim i alternativnim školama se otvaraju veće mogućnosti } \\
\text { za uvođenje inovacija u sadržajima obrazovanja. }\end{array}$ &, 626 \\
\hline 6. & U privatnim školama nastavnici imaju bolje uslove za rad. \\
\hline 1. & $\begin{array}{l}\text { U državnim školama treba ponuditi različite koncepcije vaspitanja } \\
\text { i obrazovanja kako bi roditelji mogli izabrati onaj model rada za } \\
\text { koji misle da je najbolji za njihovo dete. }\end{array}$ &, 448 \\
\hline 3. & $\begin{array}{l}\text { Privatne i alternativne škole pružaju veće prilike za kreativnost } \\
\text { nastavnika. }\end{array}$ &, 441 \\
\hline 2. & $\begin{array}{l}\text { Alternativne škole pružaju veće prilike da učenik u potpunosti } \\
\text { ostvari svoje potencijale. }\end{array}$ & \multicolumn{2}{|l}{} \\
\hline
\end{tabular}

Druga skala sadrži 11 ajtema koje su uzete kao kriterijumi za procenu distinktivnih obeležja privatnih škola u odnosu na državne škole. Ispitanicima je pružena mogućnost da na trostepenoj skali $(1$ - ne slažem se; 2 - nema razlike; 3 slažem se) izaberu jedan od ponuđenih odgovora. Rezultati faktorske analize putem koje su proveravane glavne komponente skale pokazuju da je reč o jednodimenzionalnoj skali, jer procenat objašnjene varijanse prve izolovane komponente iznosi 35,31, a druge upadljivo niže - 12,31. U prilog jednodimenzionalnosti idu i korelacije ajtema s prvom glavnom komponentom koje su sve više ili visoke, i sve preko .30 (Tabela br. 2). Ajtem koji ima upadljivo nižu, ali i dalje značajnu korelaciju sa prvom glavnom komponentom je ajtem broj 1, čija korela- 
cija iznosi .36. Rezultati faktorske analize ukazuju na visok nivo unutrašnje konzistentnosti ajtema, što potvrđuje i koeficijent relijabilnosti (Alpha koeficijent) koji iznosi 0,81 .

Tabela 2. Faktorska analiza skale o distinktivnim obeležjima privatnih škola u odnosu na državne škole

\begin{tabular}{|c|l|c|}
\hline \multicolumn{2}{|c|}{ Ajtemi } & Komponenta \\
\hline 10. & $\begin{array}{l}\text { U privatnim školama je bolja komunikacija na relaciji nastavnik - } \\
\text { roditelj. }\end{array}$ &, 677 \\
\hline 7. & U privatnim školama deca više uče strane jezike. &, 669 \\
\hline 3. & $\begin{array}{l}\text { U privatnim školama se otvaraju veće mogućnosti za uvođenje } \\
\text { inovacija u organizaciji obrazovnog procesa. }\end{array}$ &, 633 \\
\hline 9. & U privatnim školama se bolje disciplinuju problematična deca. &, 625 \\
\hline 8. & $\begin{array}{l}\text { Privatne škole su više usmerene na razvoj socijalne osetljivosti i } \\
\text { tolerancije kod učenika. }\end{array}$ &, 620 \\
\hline 4. & $\begin{array}{l}\text { U privatnim školama postoji veća uključenost roditelja u život i } \\
\text { rad škole. }\end{array}$ &, 616 \\
\hline 5. & Privatne škole karakteriše veća briga o detetu pre i nakon nastave. &, 586 \\
\hline 11. & U privatnim školama se deca više informatički opismenjavaju. &, 576 \\
\hline 6. & $\begin{array}{l}\text { Privatne škole su više usmerene na zdravu ishranu i sportske } \\
\text { aktivnosti. }\end{array}$ &, 574 \\
\hline 2. & $\begin{array}{l}\text { Privatne škole imaju bolje uslove za rad s decom s poteškoćama u } \\
\text { razvoju. }\end{array}$ &, 537 \\
\hline & $\begin{array}{l}\text { Privatne školama omogućavaju kvalitetniji rad zbog manjeg broja } \\
\text { učenika u odeljenju. }\end{array}$ &, 359 \\
\hline
\end{tabular}

Drugi deo instrumenta odnosi se na pitanja kojima se ispituje samoprocena nivoa informisanosti ispitanika o određenim alternativnim pedagoškim koncepcijama (Montesori pedagogija, Freneova pedagogija, Dekroli pedagogija, Štajner pedagogija i Korak po korak metodologija). Samoprocena nivoa informisanosti ispitanika merena je preko četvorostepene skale Likertovog tipa $(1-$ nimalo; 2 - malo; 3 - mnogo: 4 - veoma mnogo). Ovim delom upitnika obuhvaćeno je i pitanje o tome da li je potrebno povećati broj alternativnih škola u Srbiji, a svoje mišljenje o ovom pitanju ispitanici su izražavali odabirom jednog od tri ponuđena odgovora (1 - ne; 2 - neodlučan/na sam; 3 - da). Pored opcije ponuđenih odgovora, data je i opcija da ispitanici iznesu svoje argumente za odabrani odgovor.

Uzorak, tok istraživanja i statistička obrada. Uzorkom istraživanja obuhvaćeno je 99 studenata pedagogije. Od ukupnog broja ispitanika, 54,5\% su studenti II godine, a 45,5\% su studenti IV godine studija Pedagogije. Istraživanje je obavljeno na Odseku za pedagogiju, Filozofskog fakulteta Univerziteta u Novom Sadu. Za statističku obradu podataka primenjen je softverski paket SPSS 12.0. U okviru deskriptivne statistike merene su prosečne vrednosti (aritmetička sredina) i mere disperzije rezultata (standardna devijacija). U cilju ispitivanja latentne struk- 
ture merenih varijabli primenjena je faktorska analiza, a u cilju analize statističke značajnosti razlika primenjen je t-test $\mathrm{i} \chi^{2}$ test.

\section{REZULTATI ISTRAŽIVANJA}

Mišljenje ispitanika o značaju delovanja privatnih i alternativnih škola. $\mathrm{Na}$ osnovu analize deskriptivnih statističkih podataka utvrđeno je da ukupan prosečan skor za skalu koja ispituje značaj delovanja privatnih i alternativnih škola iznosi $\mathrm{M}=3,85$ uz $\mathrm{SD}=0,44$, te se može konstatovati da odgovori studenata pedagogije naginju ka pozitivnom mišljenju o značaju delovanja privatnih i alternativnih škola. U Tabeli br. 3 dat je detaljan prikaz deskriptivne statistike odgovora studenata pedagogije za svaki pojedinačni ajtem.

Tabela 3. Mišljenje studenata pedagogije o značaju delovanja privatnih i alternativnih škola

\begin{tabular}{|c|c|c|c|c|c|c|c|c|c|c|c|c|c|c|}
\hline \multirow{3}{*}{ Ajtemi } & \multicolumn{12}{|c|}{ Odgovori } & & \\
\hline & \multicolumn{2}{|c|}{1} & \multicolumn{2}{|c|}{2} & \multicolumn{2}{|c|}{3} & \multicolumn{2}{|c|}{4} & \multicolumn{2}{|c|}{5} & \multicolumn{2}{|c|}{$\begin{array}{l}\text { nedosta- } \\
\text { jući }\end{array}$} & & \\
\hline & $f$ & $\%$ & $f$ & $\%$ & $f$ & $\%$ & $f$ & $\%$ & $f$ & $\%$ & $\mathrm{f}$ & $\%$ & $\mathrm{M}$ & SD \\
\hline 1. & 1 & 1 & 5 & 5,1 & 22 & 22,2 & 42 & 42,4 & 29 & 29,3 & 0 & 0 & 3,9 & 0,9 \\
\hline 2. & 3 & 3 & 15 & 15,2 & 7 & 7,1 & 49 & 49,5 & 25 & 25,3 & 0 & 0 & 3,8 & 1,1 \\
\hline 3. & 0 & 0 & 10 & 10,1 & 9 & 9,1 & 48 & 48,5 & 32 & 32,3 & 0 & 0 & 4,0 & 0,9 \\
\hline 4. & 2 & 2 & 7 & 7,1 & 35 & 35,4 & 35 & 35,4 & 20 & 20,2 & 0 & 0 & 3,6 & 1,0 \\
\hline 5. & 6 & 6,1 & 23 & 23,2 & 41 & 41,4 & 20 & 20,2 & 9 & 9,1 & 0 & 0 & 3,0 & 1,0 \\
\hline 6. & 0 & 0 & 5 & 5,1 & 16 & 16,2 & 53 & 53,5 & 24 & 24,2 & 1 & 1 & 4,0 & 0,8 \\
\hline 7. & 1 & 1 & 2 & 2 & 9 & 9,1 & 49 & 49,5 & 38 & 38,4 & 0 & 0 & 4,2 & 0,8 \\
\hline 8. & 1 & 1 & 3 & 3 & 17 & 17,2 & 46 & 46,5 & 32 & 32,3 & 0 & 0 & 4,1 & 0,8 \\
\hline 9. & 0 & 0 & 9 & 9,1 & 38 & 38,4 & 36 & 36,4 & 16 & 16,2 & 0 & 0 & 3,6 & 0,9 \\
\hline 10. & 3 & 3 & 1 & 1 & 10 & 10,1 & 46 & 46,5 & 39 & 39,4 & 0 & 0 & 4,2 & 0,9 \\
\hline
\end{tabular}

Uvidom u Tabelu br. 3 moguće je uočiti da su najviši prosečni skorovi dobijeni kod ajtema br. $7(M=4,2)$, br. $10(M=4,2)$ i br. $8(M=4,1)$, što znači da se većina studenata pedagogije delimično ili u potpunosti slaže sa tvrdnjama da se $u$ alternativnim školama više vodi računa o potrebama i interesovanjima svakog deteta, da država treba da finansijski potpomaže otvaranje i delovanje privatnih $i$ alternativnih škola kako bi one bile jednako dostupne svoj deci, te da se u alternativnim školama odvija kvalitetnija komunikacija između nastavnika i roditelja. Najniži prosečan skor dobijen je kod ajtema br. $5(\mathrm{M}=3,0)$, s tim što je većina studenata pedagogije neodlučna (41,4\%) kada je reč o tvrdnji da se u privatnim školama učenici bolje pripremaju za nastavak obrazovanja na višim nivoima. Takođe, rezultati pokazuju da je visok procenat neodlučnog stava prisutan i kod tvrdnje br. 9 (u privatnim školama obezbeđuje se viši nivo bezbednosti učenika-38,4\%), 
kao i kod tvrdnje br. 4 (u privatnim i alternativnim školama se otvaraju veće mogućnosti za uvođenje inovacija u sadržajima obrazovanja - 35,4\%).

Mišljenje ispitanika o distinktivnim obeležjima privatnih škola u odnosu na državne škole. Na osnovu analize deskriptivnih statističkih podataka utvrđeno je da ukupan prosečan skor za skalu koja ispituje mišljenje ispitanika o distinktivnim obeležjima privatnih škola u odnosu na državne škole iznosi $\mathrm{M}=2,59 \mathrm{uz} \mathrm{SD}=0,44$, te se može konstatovati da za većinu merenih obeležja odgovori studenata pedagogije naginju ka isticanju prednosti privatnih u odnosu na državne škole. U Tabeli br. 4 dat je detaljan prikaz deskriptivne statistike odgovora studenata pedagogije za svaki pojedinačni ajtem.

Tabela 4. Mišljenje studenata pedagogija o distinktivnim obeležjima privatnih škola u odnosu na državne škole

\begin{tabular}{|c|c|c|c|c|c|c|c|c|c|c|}
\hline \multirow{2}{*}{ Pitanje } & \multicolumn{7}{|c|}{ Odgovori } & \multicolumn{2}{|c|}{} \\
\cline { 2 - 12 } & \multicolumn{2}{|c|}{1} & \multicolumn{2}{|c|}{2} & \multicolumn{2}{|c|}{3} & \multicolumn{2}{|c|}{ nedostajući } & \multicolumn{2}{|c|}{} \\
\cline { 2 - 12 } & $f$ & $\%$ & $f$ & $\%$ & $f$ & $\%$ & $f$ & $\%$ & $M$ & $S D$ \\
\hline 1. & 2 & 2 & 11 & 11,1 & 86 & 86,9 & 0 & 0 & 2,8 & 0,4 \\
\hline 2. & 1 & 1 & 11 & 11,1 & 87 & 87,9 & 0 & 0 & 2,9 & 0,4 \\
\hline 3. & 1 & 1 & 16 & 16,2 & 81 & 81,8 & 1 & 1 & 2,8 & 0,4 \\
\hline 4. & 6 & 6,1 & 42 & 42,4 & 51 & 51,5 & 0 & 0 & 2,5 & 0,6 \\
\hline 5. & 5 & 5,1 & 48 & 48,5 & 46 & 46,5 & 0 & 0 & 2,4 & 0,6 \\
\hline 6. & 0 & 0 & 53 & 53,5 & 45 & 45,5 & 1 & 1 & 2,5 & 0,5 \\
\hline 7. & 1 & 1 & 25 & 25,3 & 73 & 73,7 & 0 & 0 & 2,7 & 0,5 \\
\hline 8. & 13 & 13,1 & 43 & 43,4 & 43 & 43,4 & 0 & 0 & 2,3 & 0,7 \\
\hline 9. & 19 & 19,2 & 41 & 41,4 & 39 & 39,4 & 0 & 0 & 2,2 & 0,7 \\
\hline 10. & 3 & 3 & 25 & 25,3 & 71 & 71,7 & 0 & 0 & 2,7 & 0,5 \\
\hline 11. & 0 & 0 & 29 & 29,3 & 69 & 69,7 & 1 & 1 & 2,7 & 0,5 \\
\hline
\end{tabular}

Uvidom u Tabelu br. 4 moguće je uočiti da su najviši prosečni skorovi dobijeni kod obeležja br. $2(\mathrm{M}=2,9)$, br. $1(\mathrm{M}=2,8)$ i br. $3(\mathrm{M}=2,8)$. Naime, većina studenata pedagogije smatra da se prednost privatnih u odnosu na državne škole u najvećoj meri ogleda kod obeležja koja se odnose na uslove za rad sa decom $s$ poteškoćama u razvoju, veličinu odeljenja, kao i na veće mogućnosti za uvođenje inovacija u organizaciji obrazovnog procesa. Takođe, značajno je istaći da dobijeni prosečni skorovi i kod svih ostalih merenih obeležja pokazuju da odgovori studenata pedagogije uglavnom naginju ka isticanju prednosti privatnih u odnosu na državne škole.

Informisanost o alternativnim pedagoškim koncepcijama. Na osnovu analize dobijenih odgovora o nivou informisanosti o određenim alternativnim pedagoškim koncepcijama (Montesori pedagogija, Korak po korak metodologija, Stajner pedagogija, Dekroli pedagogija i Freneova pedagogija) utvrđeno je da srednja vrednost 
aritmetičke sredine iznosi $\mathrm{M}=2,0 \mathrm{uz} \mathrm{SD}=0,8$. Na osnovu ovakvog rezultata moguće je konstatovati da većina ispitanih studenata pedagogije procenjuje da su malo informisani o navedenim alternativnim pedagoškim koncepcijama. Rezultati prokazani u Tabeli br. 5 pokazuju da su studenti pedagogije u nešto većoj meri informisani o Montesori pedagogiji $(\mathrm{M}=2,5 \mathrm{uz} \mathrm{SD}=0,8)$ i Korak po korak metodologiji $(\mathrm{M}=2,0 \mathrm{uz} \mathrm{SD}=0,8)$, dok je nivo informisanosti za preostale tri alternativne pedagoške koncepcije relativno nizak.

Tabela 5. Nivo informisanosti studenata pedagogije o alternativnim pedagoškim koncepcijama

\begin{tabular}{|l|c|c|}
\hline Alternativna pedagoška koncepcija: & M & SD \\
\hline Montesori pedagogija & 2,5 & 0,8 \\
\hline Korak po korak & 2,0 & 0,8 \\
\hline Štajner pedagogija & 1,6 & 0,7 \\
\hline Dekroli pedagogija & 1,8 & 0,7 \\
\hline Freneova pedagogija & 1,9 & 0,9 \\
\hline \multicolumn{2}{|c|}{$\mathrm{M}=2,0 \mathrm{SD}=0,8$} \\
\hline
\end{tabular}

Rezultati prokazani u Tabeli br. 5 pokazuju da su studenti pedagogije u nešto većoj meri informisani o Montesori pedagogiji $(\mathrm{M}=2,5$ uz $\mathrm{SD}=0,8)$ i Korak po korak metodologiji $(\mathrm{M}=2,0 \mathrm{uz} \mathrm{SD}=0,8)$, dok je nivo informisanosti za preostale tri alternativne pedagoške koncepcije relativno nizak.

Mišljenje ispitanika o potrebi povećanja broja alternativnih škola u Srbiji. $\mathrm{Na}$ osnovu dobijenih odgovora o potrebi povećanja broja alternativnih škola u Srbiji, utvrđeno je da prosečan skor iznosi $\mathrm{M}=2,6$, uz $\mathrm{SD}=0,6$, što znači da je većina studenata pedagogije koji su obuhvaćeni ovim istraživanjem $(68,7 \%) \mathrm{mi}$ šljenja da treba povećati broj alternativnih škola u Srbiji. Neodlučan stav po ovom pitanju iskazalo je 26,3\% studenata pedagogije, dok je 5,1\% njih mišljenja da broj alternativnih škola u Srbiji ne treba povećavati (Tabela br. 6).

Tabela 6. Odgovori ispitanika na pitanje o potrebi povećanja broja alternativnih škola u Srbiji

\begin{tabular}{|c|c|c|c|c|c|c|c|c|c|}
\hline \multicolumn{7}{|c|}{ Da li treba povećati broj alternativnih škola u Srbiji? } & \multicolumn{2}{c|}{} \\
\hline \multicolumn{2}{|c|}{$\mathrm{Ne}$} & $\begin{array}{c}\text { Neodlučan/na } \\
\text { sam }\end{array}$ & \multicolumn{2}{c|}{ Da } & \multicolumn{2}{c|}{ Nedostajući } & \multicolumn{2}{l|}{} \\
\hline$f$ & $\%$ & $f$ & $\%$ & $f$ & $\%$ & $f$ & $\%$ & $M$ & $S D$ \\
\hline 5 & 5,1 & 26 & 26,3 & 68 & 68,7 & 0 & 0 & 2,6 & 0,6 \\
\hline
\end{tabular}

Razlike u odgovorima studenata pedagogije zavisno od godine studija. Primenom t-testa utvrđeno je da postoje statistički značajne razlike u odgovorima studenata pedagogije o značaju delovanja privatnih i alternativnih škola, zavisno od godine studija (Tabela 7). Dobijene vrednosti pokazuju da studenti IV godine 
ostvaruju više skorove, odnosno imaju pozitivnji stav prema privatnim i alternativnim školama u odnosu na studente II godine studija.

Tabela 7. Razlike u odgovorima studenata pedagogije s obzirom na godinu studija Stav o značaju delovanja privatnih i alternativnih škola

\begin{tabular}{|c|c|c|c|c|c|} 
God. studija & $M$ & $S D$ & $t$ & $d f$ & $p$ \\
\hline II & 3,76 & 0,46 & \multirow{2}{*}{$-2,21$} & \multirow{2}{*}{97} & \multirow{2}{*}{, 029} \\
\hline IV & 3,95 & 0,40 & & & \\
\hline
\end{tabular}

Takođe, statistički značajne razlike utvrđene su i kod odgovora studenata pedagogije o distinktivnim obeležjima privatnih škola u odnosu na državne, zavisno od godine studija (Tabela br. 8). Dobijene razlike pokazuju da studenti IV godine ostvaruju više skorove, odnosno u većoj meri, nego studenti II godine studija, ističu prednosti privatnih škola u odnosu na državne škole.

Tabela 8. Razlike u odgovorima studenata pedagogije s obzirom na godinu studija

Stav o distinktivnim obeležjima privatnih škola u odnosu na državne

\begin{tabular}{|c|c|c|c|c|c|} 
God. studija & $M$ & $S D$ & $t$ & $d f$ & $p$ \\
\hline II & 2,51 & 0,29 & & & \\
\cline { 1 - 3 } IV & 2,68 & 0,26 & $-3,12$ & 97 & .002 \\
\hline
\end{tabular}

Analizom t-testa utvrđeno je da postoje statistički značajne razlike u nivou informisanosti studenata pedagogije o navedenim alternativnim pedagoškim koncepcijama s obzirom na godinu studija (Tabela br. 9). Dobijeni rezultati pokazuju da su studenti IV godine u većoj meri, u odnosu na studente II godine studija pedagogije, informisani o navedenim alternativnim pedagoškim koncepcijama.

Tabela 9. Razlike u informisanosti studenata pedagogije o alternativnim pedagoškim koncepcijama s obzirom na godinu studija

\begin{tabular}{|c|c|c|c|c|c|c|}
\hline $\begin{array}{l}\text { Alternativna pedagoška } \\
\text { koncepcija }\end{array}$ & God. studija & $M$ & $\mathrm{SD}$ & $\mathrm{t}$ & $\mathrm{df}$ & $\mathrm{p}$ \\
\hline \multirow{2}{*}{ Montesori pedagogija } & II & 1,94 & 0,60 & \multirow{2}{*}{$-10,52$} & \multirow{2}{*}{91} & \multirow{2}{*}{, 000} \\
\hline & IV & 3,18 & 0,53 & & & \\
\hline \multirow{2}{*}{ Korak po korak } & II & 1,60 & 0,61 & \multirow{2}{*}{$-5,37$} & \multirow{2}{*}{90} & \multirow{2}{*}{, 000} \\
\hline & IV & 2,38 & 0,78 & & & \\
\hline \multirow{2}{*}{ Štajner pedagogija } & II & 1,33 & 0,48 & \multirow{2}{*}{$-4,73$} & \multirow{2}{*}{91} & \multirow{2}{*}{, 000} \\
\hline & IV & 1,96 & 0,77 & & & \\
\hline \multirow{2}{*}{ Dekroli pedagogija } & II & 1,42 & 0,58 & \multirow{2}{*}{$-6,22$} & \multirow{2}{*}{91} & \multirow{2}{*}{, 000} \\
\hline & IV & 2,22 & 0,67 & & & \\
\hline \multirow{2}{*}{ Freneova pedagogija } & II & 1,46 & 0,54 & \multirow{2}{*}{$-6,61$} & \multirow{2}{*}{91} & \multirow{2}{*}{, 000} \\
\hline & IV & 2,42 & 0,84 & & & \\
\hline
\end{tabular}


Kada je reč razlikama u mišljenju o potrebi povećanja broja altenativnih škola, analizom $\chi^{2}$ testa utvrđeno je da postoje marginalno značajne razlike između studenata II i IV godine $\left(\chi^{2}(2)=5,11, p=.08\right)$. Naime, iako se većina studenata slaže da broj alternativnih škola u Srbiji treba povećati, značajno veći broj studenata II godine pedagogije je neodlučan po ovom pitanju, dok su studenti IV godine pedagogije dali veći broj podržavajućih odgovora (Tabela 10).

Tabela 10. Razlike u odgovorima studenata pedagogije o potrebi povećanju broja privatnih i alternativnih škola s obzirom na godinu studija

\begin{tabular}{|c|c|c|c|c|c|c|}
\hline & \multicolumn{3}{|c|}{$\begin{array}{l}\text { Da li treba povećati broj alternativnih škola } \\
\text { u Srbiji? }\end{array}$} & \multirow[b]{2}{*}{ Ukupno } \\
\hline & & & $\mathrm{Ne}$ & $\begin{array}{l}\text { Neodlučan } \\
\text { sam }\end{array}$ & $\mathrm{Da}$ & \\
\hline \multirow{4}{*}{$\begin{array}{l}\text { Godina } \\
\text { studija }\end{array}$} & \multirow{2}{*}{ II } & $f$ & 4 & 18 & 32 & 54 \\
\hline & & $\%$ & $7,4 \%$ & $33,3 \%$ & $59,3 \%$ & $100,0 \%$ \\
\hline & \multirow{2}{*}{ IV } & $f$ & 1 & 8 & 36 & 45 \\
\hline & & $\%$ & $2,2 \%$ & $17,8 \%$ & $80,0 \%$ & $100,0 \%$ \\
\hline \multirow{2}{*}{\multicolumn{2}{|c|}{ Ukupno }} & $f$ & 5 & 26 & 68 & 99 \\
\hline & & $\%$ & $5,1 \%$ & $26,3 \%$ & $68,7 \%$ & $100,0 \%$ \\
\hline
\end{tabular}

\section{DISKUSIJA I ZAKLJUČAK}

Proces uvođenja pedagoškog i školskog pluralizma u zemljama centralne i istočne Evrope predstavljao je u velikoj meri pokušaj otklona od državne konfekcijske škole tipične za prethodni školski sistem i jedan od načina pluralizacije društva u postsovjetskoj eri. Pokazalo se, međutim, da relativno nova situacija pretpostavlja visok nivo informisanosti svih aktera školskog života o delovanju privatnih i alternativnih škola, kao i pozitivne stavove o ideji razvoja pedagoškog i školskog pluralizma (Rajić, 2008; Zuković \& Milutinović, 2013), a samim time i znatnu razvijenost pravne i građanske svesti u pogledu odgovornog izbora škole (Matulčikova, 2003). U svetlu pomenutih stanovišta, a polazeći od činjenice da je delovanje školskog i pedagoškog pluralizma u Republici Srbiji još uvek na samom početku, smatrano je da potencijalno relevantan pokazatelj pretpostavki razvoja školskog pluralizma može biti sagledan kroz analizu stavova studenata pedagogije kao budućih lidera i ključnih diseminatora ideje razvoja pedagoškog i školskog pluralizma.

Na osnovu dobijenih nalaza moguće je konstatovati da većina ispitanih studenata pedagogije Filozofskog fakulteta Univerziteta u Novom Sadu ima relativno pozitivan stav prema privatnim i alternativnim školama. U prilog ovoj konstataciju govori nalaz da se visok procenat ispitanih studenata pedagogije delimično ili u potpunosti slaže sa tvrdnjom da u državnim školama treba ponuditi različite koncepcije vaspitanja i obrazovanja kako bi roditelji mogli izabrati onaj model 
rada za koji misle da je najbolji za njihovo dete. Takođe, većina ispitanih studenata pedagogije prepoznaje značaj javnog (su)finansiranja privatnog i alternativnog obrazovanja kao načina ostvarivanja veće dostupnosti i izbora škole.

Podržavajući stav studenata pedagogije prema pluralizaciji obrazovne ponude moguće je sagledati i kroz dobijene odgovore o distinktivnim obeležjima privatnih škola u odnosu na državne škole. Naime, utvrđeno je da ispitani studenti pedagogije za većinu merenih obeležja daju blagu prednost privatnim školama, a kao posebnu prednost privatnih škola ističu uslove za rad sa decom s poteškoćama u razvoju, veličinu odeljenja i veće mogućnosti za uvođenje inovacija u organizaciji obrazovnog procesa. Dobijeni prosečni skorovi i kod ostalih merenih obeležja sugerišu da studenti pedagogije, posebno na višim godinama studija (nakon izučavanja sadržaja iz područja školskog i pedagoškog pluralizma), imaju u vidu mnoge prednosti koje proizilaze iz primene politike školskog izbora. Značajno je, na primer, istaći mišljenje ispitanika o prisutnosti veće uključenosti roditelja u život i rad škole, i bolje komunikacije na relaciji nastavnik -roditelj u privatnim školama. Ovakav nalaz je u saglasnosti sa određenim stanovištima o delovanju privatnih škola (Cox \& Witko, 2008) koja ističu da su privatne škole manje birokratski uređene i sa većim stepenom autonomije, što rezultira prijatnijim ambijentom za povećan angažman roditelja u školskim aktivnostima dece. Takođe, $\mathrm{u}$ literaturi (Kozakiewicz, 1992; Sliwka \& Istance, 2006) se ukazuje na tendencije privatnih škola da ograniče broj dece u odeljenju, da individualizuju nastavu i da intenziviraju učenje stranih jezika, počevši od prvog razreda osnovne škole.

Kada je reč o nivou informisanosti studenata pedagogije o alternativnim pedagoškim koncepcijama, može se konstatovati da ispitanici, generalno posmatrano, procenjuju da su malo informisani o alternativnim pedagoškim koncepcijama. Međutim, testiranjem značajnosti razlika u dobijenim odgovorima, utvrđeno je da su studenti IV godine informisaniji o navedenim alternativnim pedagogijama u odnosu na studente II godine studija pedagogije. Ovakav nalaz je očekivan, s obzirom na činjenicu da su studenti viših godina studija pedagogije imali veće mogućnosti da kroz programe različitih predmeta izučavaju alternativne pedagogije i srodne oblasti (na primer, školski pluralizam, ljudska i dečija prava, autonomija škole).

Sličan nalaz dobijen je i kod pitanja o potrebi povećanja broja alternativnih škola u Srbiji. Naime, značajan broj studenata pedagogije izražava pozitivan stav prema razvoju alternativnog obrazovanja, što je posebno izraženo u odgovorima dobijenim od strane studenata IV godine studija. Kvalitativna analiza odgovora studenata pokazuje da je reč, pre svega, o uverenju da se u alternativnim školama u većoj meri realizuje obrazovna praksa usmerena ka detetu (13 ispitanika), da povećanje broja alternativnih škola otvara mogućnost da roditelji odaberu onu školu za koju misle da je najbolja za njihovo dete (13 ispitanika), kao i da pluralizacija školskog sistema stvara konkurenciju među obrazovnim institucijama čime postaje sredstvo povećanja kvaliteta obrazovanja ( 9 ispitanika).

$\mathrm{Na}$ osnovu dobijenih rezultata istraživanja moguće je zaključiti da studenti pedagogije, posebno na višim godinama studija (nakon izučavanja sadržaja iz 
područja školskog i pedagoškog pluralizma), računaju na mnoge prednosti koje proizilaze iz primene politike školskog izbora. U tom kontekstu ovo istraživanje potvrđuje konstatacije nekih autora (videti: Rajić, 2008) da je, kada su u pitanju stavovi o privatnim $i$ alternativnim školama, veoma važan stepen informisanosti. Stoga, ukoliko se žele poboljšati uslovi za otvaranje i razvoj privatnih i alternativnih osnovnih škola u Srbiji, potrebno je raditi na informisanju svih aktera vaspitno-obrazovnog procesa o njihovom delovanju. Posebno je važno ukazati na potrebu uvođenja sadržaja iz područja pedagoškog i školskog pluralizma u programe učiteljskih i nastavničkih fakulteta, kao i na potrebu kontinuiranog obrazovanja nastavnika u ovoj oblasti, $i$ to putem seminara i programa stručnog usavršavanja koje bi realizovale stručne organizacije i relevantne vaspitno-obrazovne institucije. Upoznavanje sa alternativnim pedagogijama i kompleksnim pitanjima u vezi sa razvojem politike školskog izbora može doprineti razvijanju kompetencija pedagoga i nastavnika koje kreiraju pretpostavke za unapređenje kvaliteta obrazovanja.

\section{REZIME:}

U tekstu se polazi od stanovišta da promenjene okolnosti savremenog sveta obrazovanju daju ključnu ulogu u pružanju odgovora na izazove koje donose globalne razvojne promene, te da obrazovanje u pluralnom društvu zahteva prilagođavanje školskog sistema uslovima novog vremena, što u našoj obrazovnoj realnosti aktualizuje pitanje pedagoškog i školskog pluralizma. Pored činjenice da većina zemalja Evropske unije ima višedecenijsko iskustvo u funkcionisanju privatnih i alternativnih škola, u radu se naglašava da su se na samom kraju 20. veka za ove škole zainteresovale i one zemlje gde je pedagoški i školski pluralizam bio onemogućavan. U tom smislu su u mnogim zemljama centralne i istočne Evrope (Mađarska, Poljska, Češka Republika, Slovačka Republika, Republika Hrvatska ...), obrazovne reforme pokrenute procesima tranzicije, političke demokratizacije i pluralizacije društva uključivale i ponovo uspostavljanje sektora privatnog obrazovanja i osnivanje alternativnih škola. U našoj zemlji, međutim, slični uslovi stvorili su se sa značajnim zakašnjenjem, to jest praktično na samom početku 21. veka. Polazeći od stava da relativno nova situacija u našoj zemlji pretpostavlja aktivne, autonomne i odgovorne pedagoge osposobljene da odgovore na potrebe pojedinca i društva u kontekstu demokratskih procesa, cilj istraživanja odnosi se na sagledavanje stavova studenata pedagogije prema privatnim $i$ alternativnim školama. Primenjeni instrument kreiran je za potrebe ovog istraživanja, a uzorkom je obuhvaćeno 99 studenata pedagogije.

Dobijeni rezultati pokazuju da većina ispitanih studenata pedagogije Filozofskog fakulteta Univerziteta u Novom Sadu ima relativno pozitivan stav prema privatnim i alternativnim školama, pri čemu odgovori studenata uglavnom naginju ka isticanju prednosti privatnih u odnosu na državne škole. Rezultati takođe pokazuju da ispitanici, generalno posmatrano, procenjuju da su malo informisani 
o alternativnim pedagoškim koncepcijama. Međutim, utvrđeno je da su studenti IV godine informisaniji o navedenim alternativnim pedagogijama u odnosu na studente II godine. Sličan nalaz dobijen je i kod pitanja o potrebi povećanja broja alternativnih škola u Srbiji. Naime, značajan broj studenata pedagogije izražava pozitivan stav prema razvoju alternativnog obrazovanja, što je posebno izraženo u odgovorima dobijenim od strane studenata IV godine studija. Na osnovu dobijenih rezultata istraživanja moguće je konstatovati da studenti pedagogije, posebno na višim godinama studija (nakon izučavanja sadržaja iz područja školskog i pedagoškog pluralizma), računaju na mnoge prednosti koje proizilaze iz primene politike školskog izbora. Zaključuje se da je, ukoliko se žele poboljšati uslovi za otvaranje i razvoj privatnih i alternativnih osnovnih škola u Srbiji, potrebno raditi na informisanju svih aktera vaspitno-obrazovnog procesa o njihovom delovanju, kao i na uvođenju sadržaja iz područja pedagoškog i školskog pluralizma u programe nastavničkih fakulteta. Takođe se zaključuje da upoznavanje sa alternativnim pedagogijama i kompleksnim pitanjima u vezi sa razvojem politike školskog izbora može doprineti razvijanju kompetencija pedagoga i nastavnika koje kreiraju pretpostavke za unapređenje kvaliteta obrazovanja.

Dr Jovana Milutinović, dr Slađana Zuković

University of Novi Sad, Faculty of Philosophy, Department of Pedagogy

\section{PEDAGOGY STUDENTS’ ATTITUDES TOWARDS THE DEVELOPMENT OF PEDAGOGY AND SCHOOL PLURALISM}

\section{SUMMARY}

This paper starts from the premise that education in a pluralistic society requires adapting the educational system to the new conditions, which in our educational reality actualizes the question of pedagogical and school pluralism. The current situation in our country assumes that active, autonomous and responsible pedagogists are trained to respond to the needs of the individual and society in the context of the democratic process. Whereas, the aim of the research related to the assessment of pedagogy students' attitudes towards private and alternative schools. Applied instrument has been created for the purposes of this study, and the sample consisted of 99 students of pedagogy. The results show that the majority of students of Pedagogy Faculty of Philosophy in Novi Sad have a relatively positive attitude towards private and alternative schools, where students generally tend to highlight the benefits of private compared to public schools. The results also show that respondents, in general, are estimated to have been not well informed about alternative pedagogical concepts. However, it was found that the fourth-year students are more informed about alternative pedagogies in relation to the students of the second year. It is concluded that in order to improve the quality of education it is very important to inform all stakeholders of the educational process about the effects of alternative and private schools, as well as the introduction of content in the field of pedagogical and school pluralism in the curricula of faculties educating teachers.

Keywords: alternative school, the democratization of society, pedagogy and school pluralism, private schools, students of pedagogy. 


\section{LITERATURA}

Boyd, W. (2005). Markets, Choices and Educational Change. In: Hargreaves, A. (Ed.) Extending Educational Change: International Handbook of Educational Change (pp. 69-94). The Netherlands: Springer,

Cox, J. H., \& Witko, C. (2008). School Choice and the Creation of Social Capital Reexamined. American Journal of Political Science, 52(1), 142-155. doi:10.1111/j.1540-5907.2007.00304.x

Eurydice European Unit (2000). Private education in the European Union: Organisation, administration and the public authorities' role. Brussels: Eurydice European Unit.

Hirsch, D. (2002). What Works in Innovation in Education - School: A Choice of Directions. OECD/CERI: Paris.

Kozakiewicz, M. (1992). The difficult road to educational pluralism in Central and Eastern Europe. Prospects, 22(2), 207-215.

Krbec, D. (1999). Privatne škole i obrazovna politika u Hrvatskoj. Revija za obrazovnu politiku, 6(3-4), 269-290.

Matulčikova, M. (2003). Alternativne škole u Slovačkoj - savremeno stanje i perspektive. Pedagoška stvarnost, 49(3-4), 347-357.

Milutinović, J., \& Zuković, S. (2013). Educational tendencies: private and alternative schools. Hrvatski časopis za odgoj i obrazovanje (Croatian Journal of Education), 15 (Sp.Ed.No. 2), 241-266.

Milutinović, J. (2011). Alternative u teoriji i praksi savremenog obrazovanja: put ka kvalitetnom obrazovanju. Novi Sad: Savez pedagoških društava Vojvodine; Vršac: Visoka škola strukovnih studija za obrazovanje vaspitača „Mihailo Palov”.

Nagata, Y. (2006). Alternative Education: Global Perspectives Relevant to the Asia-Pacific Region. Dordrecht, The Netherlands: Springer.

OECD (1998). Škole i kvalitet. Beograd: Zavod za udžbenike i nastavna sredstva, Institut za preduzetništvo MSP BK; Zrenjanin: Tehnički fakultet „Mihajlo Pupin”.

Rajić, V. (2008). Stavovi učitelja i roditelja o razvoju privatnog i alternativnog osnovnog školstva u Republici Hrvatskoj. Odgojne znanosti, 10(2), 329-347.

Raywid, M. A. (1999). History and Issues of Alternative Schools. Education Digest, 64(9), 47-51.

Ridl, K. (2003). Alternativne škole i inovacije u obrazovanju. Pedagoška stvarnost, 49(3-4), 337-346.

Savićević, M. D. (2000). Put ka društvu učenja. Beograd: Đuro Salaj, Prosvetni pregled.

Sliwka, A., \& Istance, D. (2006). Choice, Diversity and „Exit” in Schooling - A Mixed Picture. European Journal of Education, 41(1), 45-58. doi:10.1111/j.1465-3435.2006.00245.x

Sliwka, A. (2008). The Contribution of Alternative Education. In: Innovating to Learn, Learning to Innovate (pp. 93-112). Paris: OECD Publishing. Preuzeto 8. septembra 2013, sa http://www.oecd.org/dataoecd/13/30/40805108.pdf

Spevak, Z. (2001). Alternativne škole - razvoj, pojmovni okvir i funkcije. Pedagoška stvarnost, 47(9-10), 659-665.

Vrcelj, S. (2000). Školska pedagogija. Rijeka: Filozofski fakultet.

Zakon o osnovnom obrazovanju i vaspitanju, Službeni glasnik RS. Br. 55 (2013)

Zuković, S., \& Milutinović, J. (2013). Razvoj školskog i pedagoškog pluralizma u Republici Srbiji. U: Grandić, R. (ured.) Obrazovni sistem i vrednosti iz ugla pluralizma i autonomije ličnosti (str. 79-96). Novi Sad: Pedagoško društvo Vojvodine. 